\title{
RESPON DELAPAN JENIS GULMA INDIKATOR TERHADAP PEMBERIAN CAIRAN FERMENTASI PULP KAKAO
}

\author{
Aris Faisal Pratama, Herry Susanto \& Dad R. J. Sembodo \\ Jurusan Agroteknologi, Fakultas Pertanian Universitas Lampung \\ Jl.Prof. Soemantri Brodjonegoro, No.1 Bandar Lampung 35145 \\ E-mail: pratamaaris@ymail.com
}

\begin{abstract}
ABSTRAK
Cairan fermentasi pulp kakao merupakan salah satu hasil sampingan dari pengelolaan kakao, yang masih belum termanfaatkan secara optimal. Berdasarkan hasil uji awal yang dilakukan, cairan fermentasi pulp kakao memiliki potensi untuk dijadikan sebagai bioherbisida. Penelitian ini bertujuan untuk mengetahui daya racun yang terkandung dalam cairan fermentasi pulp kakao dan jenis gulma yang dapat teracuni. Penelitian ini dilaksanakan di kebun percobaan Desa Hajimena, Kecamatan Natar, Kabupaten Lampung Selatan dari Febuari sampai Juli 2012. Perlakuan disusun secara faktorial (2 x 8) dalam rancangan strip plot dengan tiga ulangan. Faktor pertama fermentasi pulp kakao dan faktor kedua delapan jenis gulma indikator. Data yang didapat dianalisis ragam dan apabila terdapat perbedaan nilai tengah perlakuan, dilanjutkan dengan uji Beda Nyata Terkecil (BNT) pada taraf $\alpha 0,05$. Hasil penelitian menunjukkan cairan fermentasi pulp kakao memiliki kandungan asam organik yang dapat meracuni delapan jenis gulma indikator. Persentase keracunan gulma golongan rumput $83 \%$, daun lebar $41 \%$, dan teki $33 \%$. Gulma golongan rumput memiliki persentase keracunan paling tinggi, sedangkan golongan teki persentase keracunannya paling rendah. Bobot kering brangkasan delapan gulma indikator, baik diaplikasi cairan fermentasi pulp kakao maupun yang tidak diaplikasi, tidak terjadi perbedaan. Hal ini menunjukkan bahwa kandungan zat yang terdapat dalam cairan fermentasi pulp kakao dapat meracuni gulma, tetapi tidak dapat menekan dan mengendalikan pertumbuhan gulma.
\end{abstract}

Kata Kunci: fermentasi, pulp kakao bioherbisida.

\section{PENDAHULUAN}

Tanaman kakao (Theobroma cacao L.) merupakan salah satu komoditas eksport non migas Indonesia, baik sebagai sumber penghidupan bagi petani produsen maupun penyumbang devisa negara dari subsektor perkebunan. Sejauh ini, kakao dimanfaatkan sebagai bahan penyedap yang digunakan untuk produksi makanan, kue, minuman, bahan kosmetik dan sumber lemak nabati (Sunarto,1992).

Salah satu hasil sampingan yang diperoleh dari pengelolaan kakao adalah pulp. Pulp merupakan lapisan berwarna putih yang melapisi permukaan biji kakao (Nasution et al., 1985). Di Indonesia limbah pulp kakao belum banyak digunakan. Kandungan kadar glukosa dan sukrosa antara $12-15 \%$, asam-asam organik serta beberapa asam amino, cukup baik digunakan dalam proses fermentasi untuk menghasilkan asam asetat (Opeke, 1984 dan Effendi, 2002).

Pulp kakao memiliki peluang besar dalam pemanfataannya. Sejauh ini limbah pulp kakao digunakan sebagai substrat untuk produksi etanol, asam sitrat, protein sel tunggal dan bahan-bahan makanan yang melalui proses fermentasi. Cairan fermentasi pulp kakao dapat dimanfaatkan sebagai substrat produksi alkohol dan asam asetat, sehingga perlu dilakukan dan dicari metode pengolahan limbah kakao yang dapat menangani dalam jumlah besar, sehingga limbah dapat termanfaatkan.

Berdasarkan hasil uji awal yang telah dilakukan oleh peneliti, bahwa fermentasi pulp kakao memiliki potensi untuk mengendalikan gulma, sehingga dapat digunakan sebagai bioherbisida. Oleh karena itu, peneliti melakukan pengujian respon delapan jenis gulma indikator terhadap pemberian cairan fermentasi pulp kakao, guna mendukung sitem pertanian berkelanjutan yang ramah lingkungan dengan menggunakan bioherbisida.

Penelitian ini bertujuan untuk mengetahui daya racun cairan fermentasi pulp kakao terhadap delapan jenis gulma indikator secara pascatumbuh dan mengetahui golongan gulma yang mampu dikendalikan oleh pemberian cairan fermentasi pulp kakao.

\section{METODE PENELITIAN}

Penelitian dilaksanakan di kebun percobaan Desa Hajimena Kecamatan Natar, Kabupaten Lampung Selatan, dari bulan Februari sampai dengan Juli 2012. Bahan yang digunakan dalam penelitian adalah delapan 
jenis gulma indikator, yang terdiri dari golongan rumput: Setaria plicata, Paspalum conjugatum,dan_Axonopus compressus, Golongan teki: Cyperus kyllingia dan Cyperus rotundus, Golongan daun lebar Asystasia gangetica, Borreria latifolia, dan Richardia brasiliensis, serta cairan fermentasi buah kakao. Alat yang digunakan adalah knapsack sprayer, nozzle biru, meteran, cangkul, tali rafia, cutter, ember, gelas ukur $500 \mathrm{ml}$, timbangan, oven, alat tulis, penggaris, dan perlengkapan lainnya. Perlakuan disusun secara faktorial $(2 \mathrm{x}$ 8) dalam rancangan strip plot dengan tiga kali ulangan. Faktor pertama adalah aplikasi fermentasi pulp kakao dan faktor kedua adalah delapan jenis gulma indikator yang ditanam pada lahan penelitian. Homogenitas ragam antar perlakuan diuji dengan uji Bartlet, aditivitas data diuji dengan uji Tuckey. Untuk membedakan nilai tengah perlakuan, dilakuan uji Beda Nyata Terkecil (BNT) pada taraf $\alpha 0,05$, dan untuk data persen keracunan ditampilkan dalam bentuk grafik.

Buah kakao yang telah dipecah, dipisahkan bijinya, dan dimasukkan kedalam karung, karung di ikat, ditindih dengan batu, setelah beberapa saat cairan pulp akan mengalir dari karung. Cairan ditampung menggunakan ember, dan di simpan kedalam botol selama 7 hari agar terjadi fermentasi.

Petak perlakuan masing-masing dibuat sebanyak 16 petak dengan 3 ulangan. Tanah yang telah diolah, dibuat petak berukuran $1,5 \mathrm{~m}$ x $0,5 \mathrm{~m}$, kemudian delapan jenis gulma indikator dari bibit yang sama ukuran, ditanam pada petak yang ada. Penanaman gulma dilakukan dengan cara menanam sejumlah 30 gulma indikator yang seragam per petakan. Jika ada gulma yang tidak tumbuh dilakukan penyulaman pada 2-3 hari setelah penanaman.
Aplikasi larutan fermentasi maupun kontrol (air) dilakukan sekali pada gulma setelah terjadi penutupan mencapai $75 \%$. Gulma yang tumbuh dirapikan, untuk mendapatkan luasan bidang semprot yang sama pada setiap petak. Pengamatan dimulai dari 1 hari setelah aplikasi (HSA) hingga 15 HSA. Peubah yang diamati dalam percobaan ini meliputi tingkat keracunan gulma dan bobot kering gulma total, untuk masing-masing golongan.

\section{HASIL DAN PEMBAHASAN}

Tingkat Keracunan Gulma. Hasil pengamatan persentase keracunan gulma menunjukkan bahwa keracunan untuk semua golongan gulma akibat pengaplikasian cairan fermentasi pulp kakao, mulai terjadi pada 1 HSA dan terus meningkat hingga 3 HSA. Pada 6 HSA mulai terjadi penurunan keracunan gulma hingga 15 HSA (Gambar 1-5).

Dari hasil pengamatan persentase keracunan setiap golongan gulma menunjukkan bahwa jenis gulma golongan rumput mengalami keracunan tertinggi dibandingkan dengan gulma golongan teki dan daun lebar (Gambar 2). Gulma golongan rumput menunjukkan bahwa $A$. compresus mengalami keracunan tertinggi dibandingkan dengan $P$. conjugatum dan $S$. plicata (Gambar 3). Gulma golongan daun lebar B. latifolia mengalami keracunan tertinggi dibandingkan dengan $A$. gangetica dan $R$. brasiliensis (Gambar 4). Gulma teki golongan menunjukkan respon $C$. kyllingia memiliki persentase keracunan lebih tinggi daripada $C$. rutundus (Gambar 5).

Pada 1 HSA keracunan delapan jenis gulma indikator mulai terjadi dan terus meningkat hingga 4

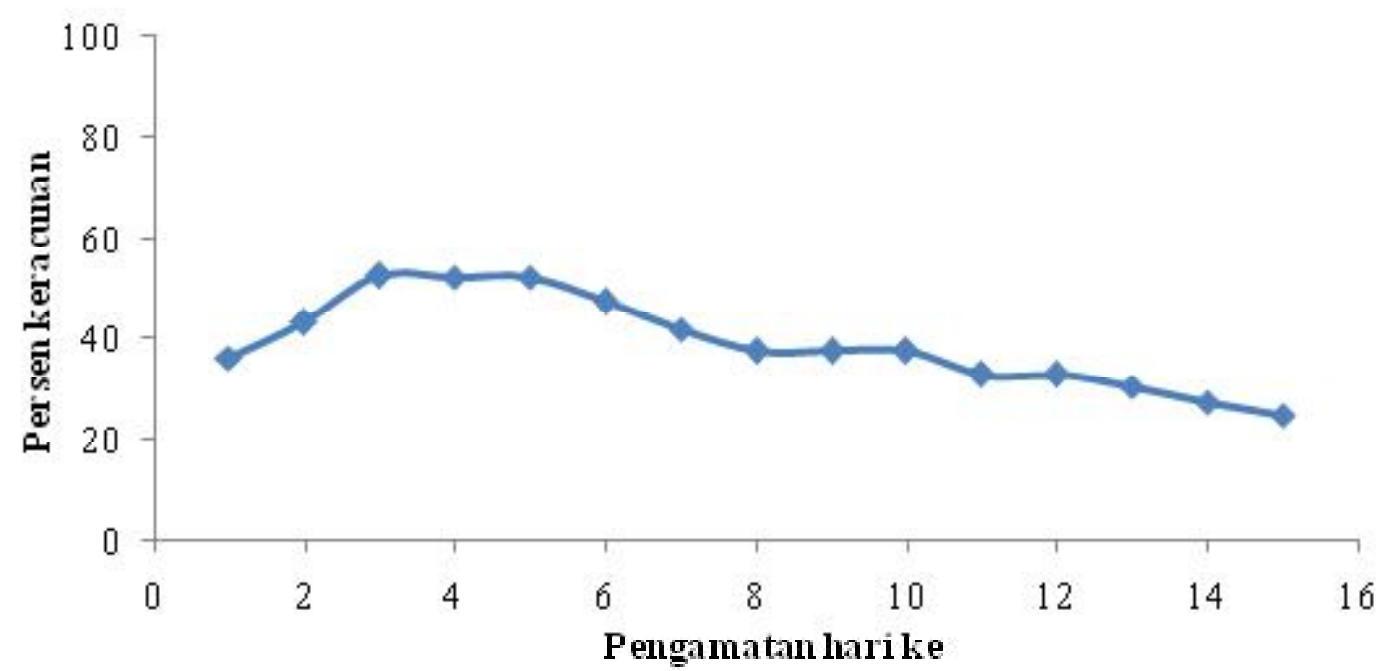

Gambar 1. Keracunan gulma total akibat aplikasi cairan fermentasi pulp kakao pada 1 HSA - 15HSA. 


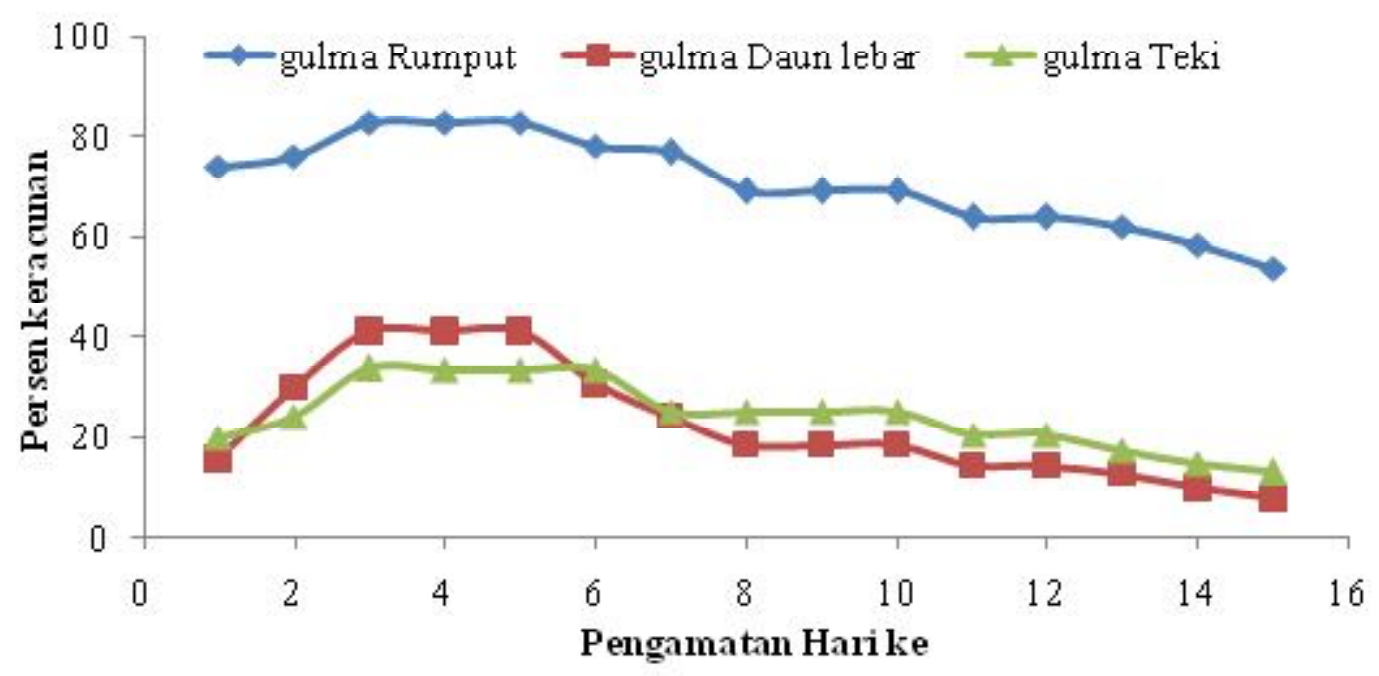

Gambar 2. Keracunan tiga golongan gulma akibat aplikasi cairan ferementasi pulp kakao pada 1 HSA - 15 HSA.

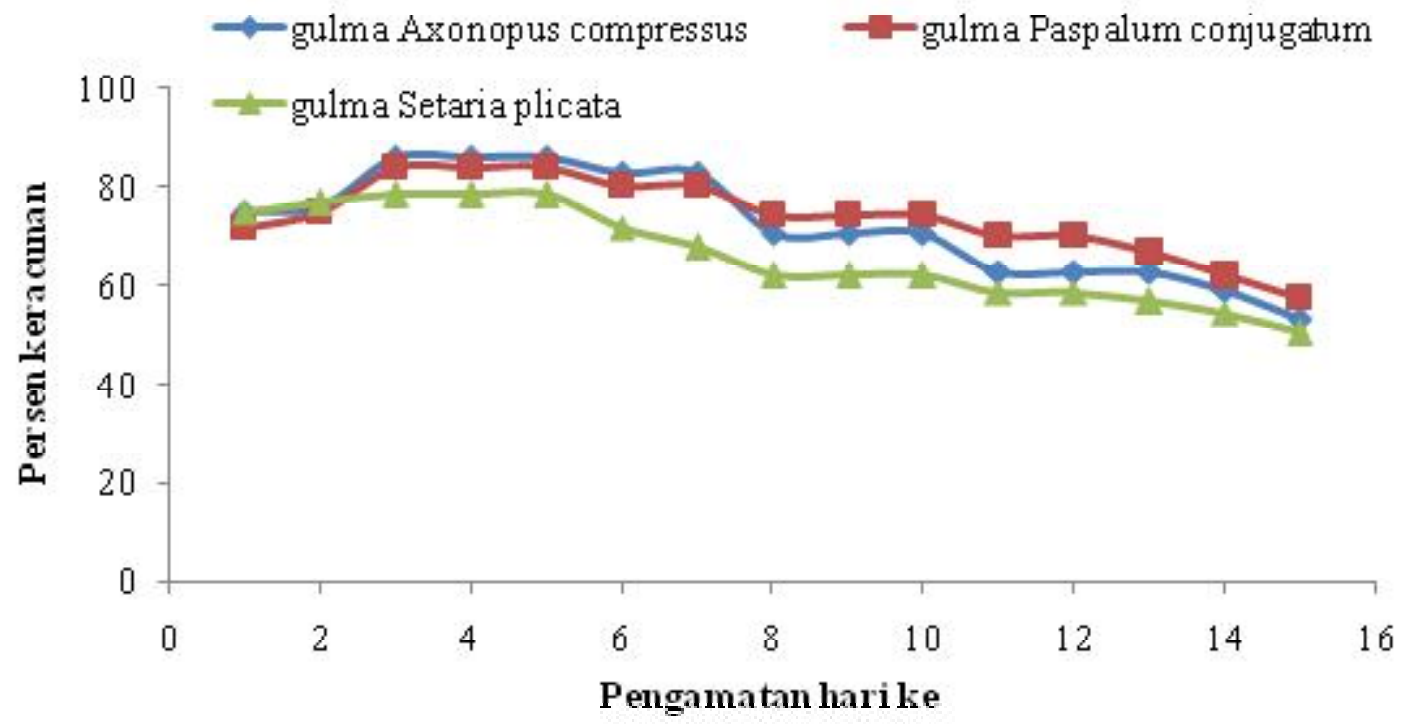

Gambar 3. Keracunan gulma rumput akibat aplikasi cairan ferementasi pulp kakao pada 1 HSA - 15 HSA.

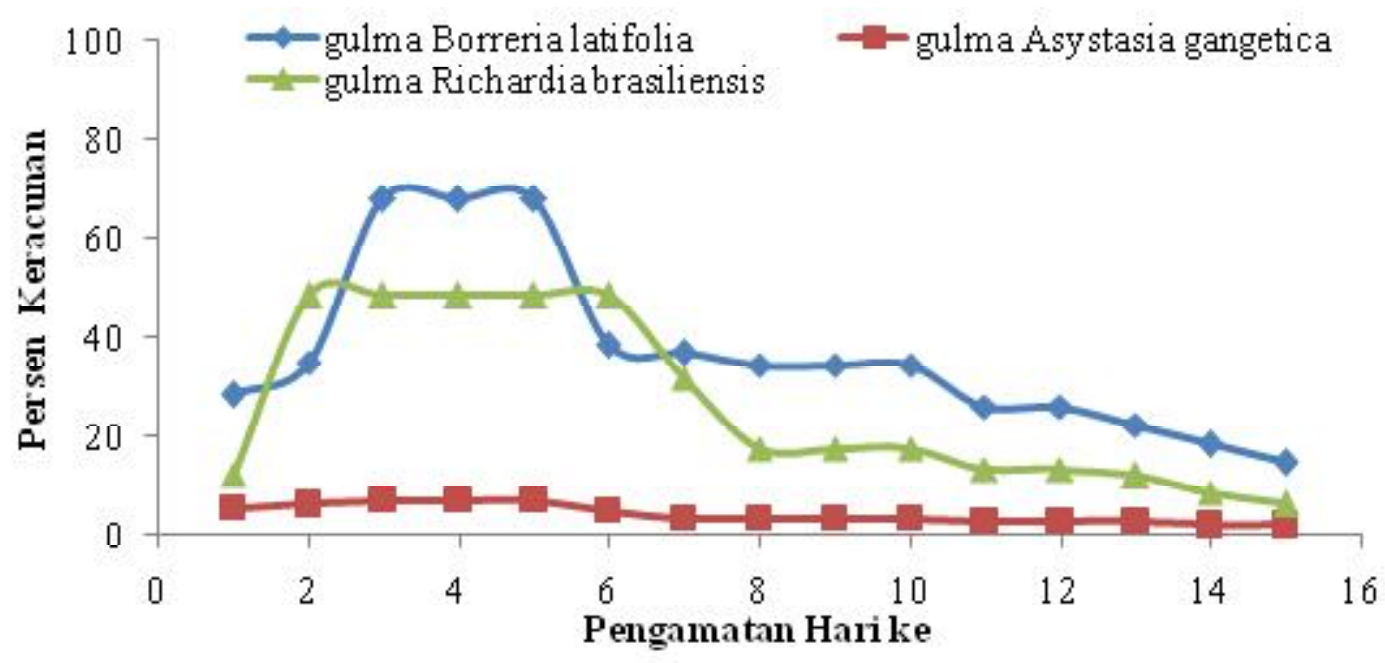

Gambar 4. Keracunan gulma daun lebar akibat aplikasi cairan ferementasi pulp kakao pada 1 HSA - 15 HSA 


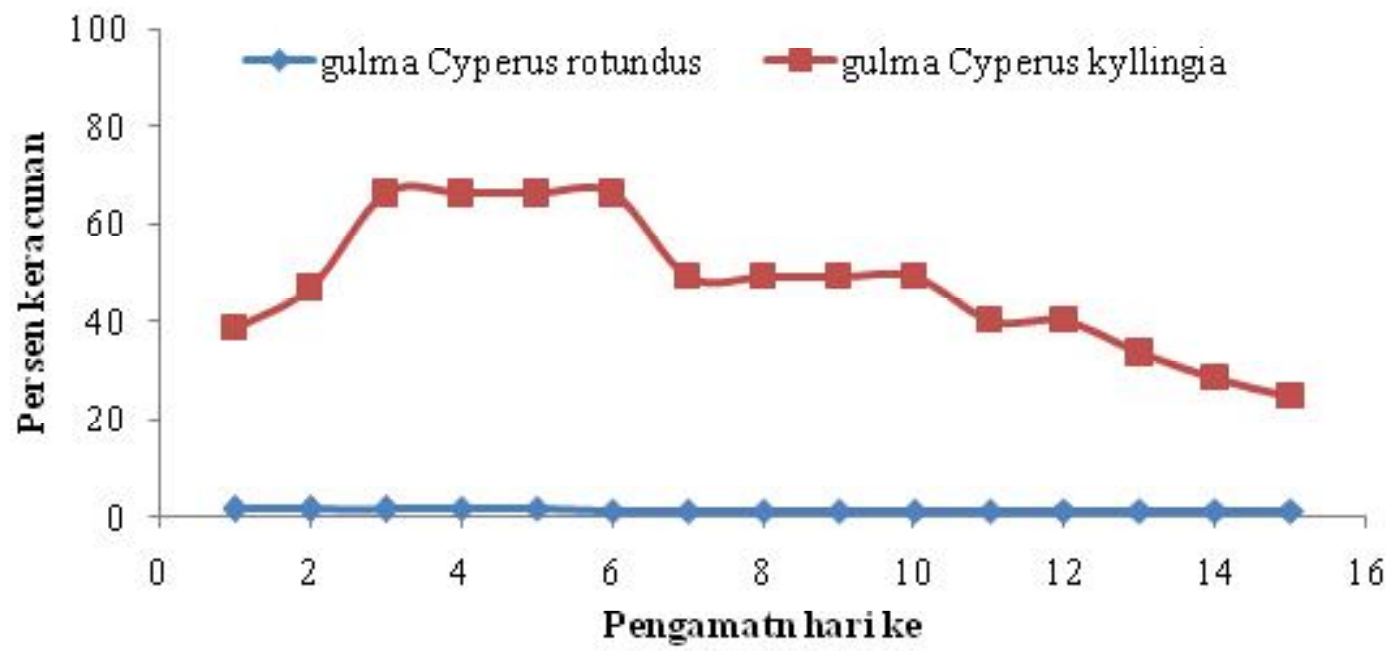

Gambar 5. Keracunan gulma teki akibat aplikasi cairan ferementasi pulp kakao pada 1 HSA - 15 HSA.

HSA. Respon dari masing-masing gulma setelah diaplikasikan cairan fermentasi pulp kakao berbeda-beda untuk tiap jenisnya, hal ini terlihat dari persen keracunan gulma yang berbeda untuk tiap jenis gulma walaupun masih dalam satu golongan. Pada 4 HSA merupakan puncak respon keracunan gulma indikator. Jenis gulma golongan rumput $A$. compressus, $P$. conjugatum, dan S. plicata menunjukan respon keracunan paling tinggi dibandingkan dengan jenis gulma indikator yang lain. Pada 7 HSA mulai terjadi penurunan persentase keracunan gulma hingga 15 HSA (Gambar 2).

Sembodo (2010) menyatakan bahwa gulma dari spesies yang samapun kadangkala memberikan respon yang berbeda terhadap herbisida tertentu. Apalagi antarjenis gulma walaupun dalam satu golongan tertentu, respon yang ditunjukkan sering berbeda. Menurut Fadhly dan Tabri (2004) setiap golongan gulma memiliki respon yang berbeda atas penerimaan herbisida. Herbisida memiliki efektifitas yang beragam, berdasarkan cara kerjanya.

Berdasarkan gejala dan sifat umum yang ditunjukkan gulma setelah diaplikasikan cairan fermentasi pulp kakao, kemampuan cairan pulp kakao hampir sama dengan herbisida kontak, Herbisida kontak sistem kerjanya langsung mematikan jaringan atau bagian gulma yang terkena larutan herbisida, terutama bagian gulma berwarna hijau yang aktif berfotosintesis, dan mampu mematikan gulma secara cepat, 2-3 jam setelah disemprot gulma sudah layu dan 2-3 hari kemudian mati, gulma akan pulih dan tumbuh kembali secara cepat sekitar 1 minggu atau 7 HSA. Bagian tumbuhan di bawah tanah seperti akar atau akar rimpang tidak terpengaruhi, sehingga dapat kembali pulih karena proses kerja pada herbisida ini pun sangat cepat.
Salisbury dan Ross (1995) menyatakan bahwa asam polifenol dapat bersifat racun bagi tanaman sehingga mengganggu pertumbuhan tanaman. Selanjutnya menurut Devi et al (1997) menyatakan bahwa senyawa polifenol menghambat pertumbuhan tanaman melalui beberapa cara, antara lain dengan menghambat pembelahan dan pemanjangan sel, menghambat kerja hormon, mengubah pola kerja enzim, menghambat proses respirasi, menurunkan kemampuan fotosintesis, mengurangi pembukaan stomata, menghambat penyerapan air dan hara serta menurunkan permeabilitas membran. Polifenol merupakan senyawa kimia yang banyak dimanfaatkan sebagai insektisida, herbisida dan fungisida. Fenol sangat tinggi toksisitasnya, bersifat non selektif dan bekerja secara efektif sebagai herbisida organik dan sebagian besar bersifat kontak (Oudejans, 1991)

Bobot Kering Gulma. Data bobot kering delapan gulma indikator menunjukkan bahwa perlakuan jenis gulma menghasilkan bobot kering gulma yang berbeda (Tabel1). Perlakuan aplikasi pulp kakao tidak mempengaruhi bobot kering gulma. Untuk persen penekanan gulma setelah diaplikasikan pulp kakao, gulma $R$. brasiliensis memiliki persen penekanan paling tinggi hingga mencapai $48 \%$. Hal ini terjadi karena gulma $R$. brasiliensis membutuhkan waktu yang lama untuk pulih setelah teracuni. Sedangkan untuk Gulma $P$. conjugatum dan $C$. kyllingia tidak terjadi penekanan pertumbuhan setelah diaplikasikan cairan fermentasi pulp kakao.

A. compressus memiliki bobot kering terbesar dibanding dengan gulma yang lain, diikuti dengan $P$. conjugatum dan S. plicata. Hal ini tetap menunjukkan 
Tabel 1. Pengaruh aplikasi pulp dan jenis gulma terhadap bobot kering delapan gulma indikator

\begin{tabular}{|c|c|c|c|}
\hline \multirow{2}{*}{ Perlakuan jenis gulma } & \multicolumn{2}{|c|}{ Bobot kering gulma total $\left(\mathrm{g} / 0,25 \mathrm{~m}^{2}\right)$} & \multirow{2}{*}{ Penekanan $(\%)$} \\
\hline & Diaplikasi & Tidak diaplikasi & \\
\hline Axonopus compressus & 128,70 & 197,39 & 35 \\
\hline Paspalum conjugatum & 108,50 & 98,30 & -10 \\
\hline Setaria plicata & 82,01 & 132,08 & 38 \\
\hline Borreria latifolia & 7,29 & 8,26 & 12 \\
\hline Asystasia gangetica & 78,08 & 82,70 & 5 \\
\hline Richardia brasiliensis & 43,22 & 83,67 & 48 \\
\hline Cyperus rotundus & 8,16 & 11,02 & 26 \\
\hline Cyperus kyllingia & 58,75 & 21,91 & -17 \\
\hline \multicolumn{4}{|l|}{ Perlakuan aplikasi pulp kakao } \\
\hline Diaplikasi & \multicolumn{2}{|c|}{$64,30 \quad \mathrm{a}$} & \\
\hline Tidak diaplikasi & \multicolumn{2}{|c|}{$79,40 \quad \mathrm{a}$} & \\
\hline BNT 0,05 & \multicolumn{2}{|c|}{21,70} & \\
\hline
\end{tabular}

Keterangan: Nilai tengah pada kolom yang sama, yang diikuti oleh huruf yang sama tidak berbeda menurut Uji pada uji BNT $\alpha_{0,05}$.

bahwa, gulma golongan rumput memiliki bobot kering tertinggi dibandingkan dengan golongan gulma yang lain. Ini terjadi dimungkinkan karena pemulihan dan pertumbuhan gulma golongan rumput, lebih cepat dibandingkan dengan jenis gulma yang lain, dan pengambilan bobot kering gulma pun dilakukan saat gulma sudah pulih dari pengaruh cairan fermentasi pulp kakao. Akan tetapi, untuk bobot kering gulma yang diaplikasi pulp kakao dengan yang tidak, memiliki nilai yang tidak berbeda. Ini menandakan bahwa, pulp kakao hanya dapat meracuni gulma, tetapi tidak dapat menekan pertumbuhan gulma.

\section{KESIMPULAN}

Berdasarkan hasil penelitian dapat diambil kesimpulan Kandungan asam yang tedapat dalam cairan fermentasi pulp kakao dapat meracuni delapan jenis gulma indikator yang digunakan dalam penelitian, namun tidak dapat menekan maupun mengendalikan gulma. Golongan gulma rumput memiliki persentase keracunan paling tinggi pada 4 HSA, dibandingkan dengan golongan gulma yang lain hingga mencapai $85 \%$ pada hari keempat setelah aplikasi.

\section{DAFTAR PUSTAKA}

Devi, S.R., Pellisier and Prasad. 1997. Allelochemical. In: M.N.V.Prasad (Eds).1997. Plant Ecophysiology. John Willey and Sons, Inc. Toronto, Canada. 253-303.

Effendi, M.S. 2002. Kinetika fermentasi asam asetat (vinegar) oleh bakteri Acetobacter aceti B127 dari etanol hasil fermentasi limbah cair pulp kakao. J Teknol Ind Pert 13:125-135.

Fadhly, dan Tabri. 2004. Pengendalian Gulma pada Pertanaman Jagung. Pusat dan Pengembangan Tanaman Pangan. Vol 12: 243

Nasution, M. Z.W. Tjiptadi, B.S. Laksmi. 1985. Pengolahan Cokelat. Bogor: Agroindustri Press. 155 hlm.

Oudejans, JH. 1991. Agro Pesticides: Properties and Function in Integrated Crop Protection.

United Nations Bangkok. 329p.

Opeke LK. 1984. Optimising economic returns (profit) from cocoa cultivation trough economic efficient use of cocoa by product. Dalam Sulistyowati, Atmawinata O, Muloto S, Yusianto. 1998. Pemenfaatan limbah bubur pulp kakao untuk pembuatan nata kakao. Pelita Perkebunan 14: 63 - 75 
Salisbury, F.B. dan C.W. Ross. 1995. Fisiologi Tumbuhan. Terjemahan Lukman dan

Sunaryono. ITB, Bandung. 338p.
Sunarto, H. 1992. Cokelat Budidaya, Pengolahan Hasil, dan Aspek Ekonominya. Penerbit Kasinus. Yogyakarta. $130 \mathrm{hlm}$.

Sembodo, D. R. J. 2010. Gulma dan pengelolaanya.

Graha Ilmu Yogyakarta. $166 \mathrm{hlm}$. 